\title{
Faktor-Faktor yang Mempengaruhi Minat Mahasiswa Mengikuti Pendidikan Magister Akuntansi
}

\author{
Ni Ketut Wardayanti ${ }^{1}$ \\ Fakultas Ekonomi dan Bisnis \\ Universitas Udayana, Indonesia
}

\author{
Made Gede Wirakusuma² \\ Fakultas Ekonomi dan Bisnis \\ Universitas Udayana, Indonesia
}

Surel : ketutwardayanti98@gmail.com

\section{ABSTRAK}

Magister akuntansi merupakan jenjang lanjutan pendidikan dari perguruan tinggi guna memperoleh gelar master. Penelitian ini bertujuan mendapatkan bukti empiris pengaruh motivasi, akreditasi program studi, pertimbangan pasar kerja dan lingkungan teman sebaya pada minat mahasiswa dalam memperoleh gelar magister akuntansi. Penelitian dilakukan di Fakultas Ekonomi dan Bisnis (FEB), Universitas Udayana. Teknik purposive sampling digunakan untuk menentukan jumlah sampel dan diperoleh 168 sampel. Data dianalisis menggunakan analisis regresi linear berganda. Hasil penelitian ini menunjukkan bahwa motivasi, dan lingkungan teman sebaya berpengaruh positif terhadap minat mahasiswa dalam memperoleh gelar magister akuntansi, sedangkan akreditasi program studi dan pertimbangan pasar kerja tidak mempengaruhi minat untuk mengikuti program pendidikan magister akuntansi.

Kata Kunci: Motivasi, Akreditasi Program Studi; Pertimbangan Pasar Kerja; Lingkungan Teman Sebaya; Minat Mahasiswa.

\section{Factors Affecting Student Interest in Taking Masters in Accounting}

\section{ABSTRACT}

Master of Accounting is a secondary education in higher education to get a master's degree. This study aims to obtain empirical evidence of the effect of motivation, accreditation of study program, labor market considerations and peer environment status on intention to take master in accounting. The research was conducted at The Faculty of Economics and Business. The sampling technique use was purposive sampling and obtained a sample of 168 samples. Data were analyzed using multiple linear regression analysis. The result of this study indicate that motivation and peer environment status has a positive effect on intention of students to take Master of Accounting Education, while accreditation of study program and labor market considerations has no effect on the interest of student attending the master of Accounting Education.

Keywords: $\quad$ Motivation; Accreditation Of Study Program; Labor Market Considerations; Peer Status; Student Interest.

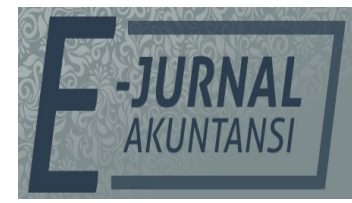

e-ISSN 2302-8556

Vol. 31 No. 7

Denpasar, Juli 2021 Hal. 1720-1731

DOI:

10.24843/EJA.2021.v31.i07.p09

PENGUTIPAN:

Wardayanti, N.K., \&

Wirakusuma, M.G. (2021).

Faktor-faktor yang

Mempengaruhi Minat

Mahasiswa Mengikuti

Pendidikan Magister

Akuntansi. E-Jurnal

Akuntansi, 31(7), 1720-1731

RIWAYAT ARTIKEL: Artikel Masuk: 16 Januari 2021

Artikel Diterima: 29 Maret 2021

Artikel dapat diakses : https://ojs.unud.ac.id/index.php/Akuntansi/index 


\section{PENDAHULUAN}

Salah satu program studi yang diminati oleh mahasiswa ekonomi dan bisnis adalah akuntansi, terlihat dari banyaknya mahasiswa yang memilih departemen akuntansi yang cenderung meningkat dari tahun ke tahun. Ada banyak alasan bagi mahasiswa memilih departemen akuntansi, diantaranya, Pertama, pasca memperoleh gelar sarjana program studi akuntansi, mahasiswa S1 dapat langsung terjun ke dunia kerja. Kedua, setelah memperoleh gelar sarjana, para sarjanawan dapat melanjutkan pendidikan profesional. Ketiga, para sarjana dapat langsung melanjutkan ke gelar master (Aryani \& Erawati, 2016). Salah satu univeritas penyelenggara program magister akuntansi adalah Universitas Uadayana. Program magister akuntansi diperuntukkan bagi sarjana ekonomi yang ingin memperoleh gelar magister akuntansi, dimana mahasiswa diharuskan menempuh pendidikan selama dua tahun untuk memperoleh gelar Magister Akuntansi (M.Si).

Motivasi merupakan salah satu faktor yang memengaruhi keinginan untuk melanjutkan pendidikan. Suatu proses dimana individu mengenali kebutuhannya dan mengambil langkah untuk memenuhi kebutuhan tersebut merupakan salah satu pengertian dari motivasi (Malik, 2017). Penelitian oleh Verawati (2016) menunjukkan bahwa motivasi dapat meningkatkan intensi dari mahasiswa dalam mengambil keputusan melanjutkan pendidikan magister.

Selain itu, kualitas program studi yang dapat terlihat dari akreditasi merupakan faktor lain yang mempengaruhi minat mahasiswa akuntansi dalam menempuh studi Magister Akuntansi. Akreditasi program studi adalah kegiatan yang menilai kelayakan suatu rencana studi. Selain akreditasi, minat mahasiswa pada program magister akuntansi juga dipengaruhi oleh faktor lain yaitu pertimbangan pasar kerja. Pertimbangan pasar kerja dapat diartikan sebagai segala sesuatu yang harus dipertimbangkan individu ketika memutuskan untuk menekuni suatu profesi, karena setiap profesi memiliki peluang yang berbedabeda. Industri dengan peluang kerja yang luas lebih disukai daripada industri dengan peluang kerja yang lebih sempit (Dary \& Ilyas, 2019). Selain faktor personal, ada juga motif sosial, salah satunya adalah lingkungan teman sebaya (Zulfa at al., 2018). Dalam mengambil keputusan terkait masa depan, individu sangat dipengaruhi oleh lingkungan teman sebayanya. Seseorang cenderung mempercayai atau melakukan sesuatu disebabkan oleh teman sebayanya atau mayoritas orang mempercayai atau melakukan hal tersebut.

Tabel 1. Perkembangan Mahasiswa Magister Akuntansi Fakultas Ekonomi dan Bisnis Universitas Udayana

\begin{tabular}{cc}
\hline Tahun & $\begin{array}{c}\text { Jumlah Mahasiswa } \\
\text { Magister Akuntansi }\end{array}$ \\
\hline 2017 & 222 \\
2018 & 171 \\
2019 & 160 \\
\hline
\end{tabular}

Sumber : Fakultas Ekonomi dan Bisnis Universitas Udayana, 2020

Terlihat dari Tabel 1, dari tahun 2017 hingga 2019 jumlah mahasiswa Magister Akuntansi mengalami penurunan. Hal inilah mendorong peneliti melakukan penelitian tentang dampak motivasi, akreditasi program studi, pertimbangan pasar kerja dan lingkungan teman sebaya terhadap minat 
mahasiswa dalam memperoleh gelar magister akuntansi untuk mengetahui apakah keempat variabel independen yang digunakan dapat meningkatkan partisipasi mahasiswa dalam menempuh pendidikan magister akuntansi atau tidak.

Teori motivasi Maslow menjelaskan bahwa kebutuhan manusia terdiri dari suatu hierarki. Kebutuhan dasar adalah kebutuhan fisiologis, dan kebutuhan tertinggi adalah kebutuhan aktualisasi diri. Motivasi memegang peranan yang cukup besar dalam menentukan minat seseorang dalam memperoleh gelar magister di bidang akuntansi.Hal tersebut disebabkan kurangnya pengetahuan profesional untuk menciptakan lapangan kerja dan motivasi serta wawasan tentang materi akuntansi yang diberikan oleh perguruan tinggi, sehingga mengakibatkan kurangnya keinginan mahasiswa. untuk terus belajar pada tingkat pendidikan mereka lebih tinggi (Giantari \& Ramantha, 2019). Oleh karena itu, motivasi memainkan peran yang cukup besar dalam menentukan minat seseorang dalam meraih gelar magister di bidang akuntansi, karena dengan meraih gelar magister di bidang akuntansi, seseorang dapat memperoleh keterampilan, kualitas, gelar, pekerjaan dan pengetahuan yang baik di bidang akuntansi.

Surya (2019) menemukan bahwa pemilihan PPAk didorong oleh banyak faktor, seperti keselamatan kerja dan potensi pendapatan di masa depan. Inilah beberapa faktor pendorong yang menentukan minat seseorang untuk memperoleh gelar master di bidang akuntansi. Penelitian yang dilakukan oleh Irma \& Hartati (2019) menunjukkan bahwa motivasi mempunyai pengaruh positif yang signifikan terhadap minat mengikuti pendidikan profesi akuntansi. Dalcı et al (2013) menunjukkan bahwa minat mahasiswa dalam memilih jurusan akuntansi sebagian besar dipengaruhi oleh faktor kelembagaan, seperti kepuasan kerja, peluang inovasi, dan lingkungan kerja yang menantang dan dinamis. Apabila mahasiswa akuntansi termotivasi, mereka akan cenderung tertarik dengan gelar master di bidang akuntansi.

$\mathrm{H}_{1}$ : Motivasi berpengaruh positif terhadap minat mengikuti pendidikan magister akuntansi.

Akreditasi suatu program studi merupakan tahap untuk mengevaluasi kualitas serta kelayakan bidang keilmuan oleh organisasi atau lembaga independen selain perguruan tinggi. Berdasarkan pengaruh timbal balik dari berbagai standar dalam standar pendidikan tinggi nasional, rencana studi disertifikasi. Proses sertifikasi diwakili oleh status sertifikasi dari rencana pembelajaran yaitu bersertifikat dan tidak bersertifikat. Verawati (2016) melakukan studi empiris pada mahasiswa akuntansi dan menemukan bahwa terdapat hubungan positif antara akreditasi program studi dengan minat memperoleh gelar magister akuntansi. Kebijakan akreditasi program studi tersebut akan berdampak pada pembentukan visi dan misi yang diarahkan ke masa depan perguruan tinggi dan menuntut perguruan tinggi untuk menghasilkan produk-produk berkualitas yang memenuhi kebutuhan masyarakat. Semakin baik akreditasinya, berdampak pada semakin tingginya intensi mahasiswa dalam meraih gelar master di bidang akuntansi.

$\mathrm{H}_{2}$ : Akreditasi program studi berpengaruh positif terhadap minat mengikuti Pendidikan magister akuntansi. 
Salah satu hal yang harus diperhatikan seseorang ketika akan memilih pekerjaan adalah pertimbangan pasar kerja, karena peluang yang dimiliki setiap profesi jelas berbeda. Biasanya, individu lebih tertarik untuk memilih karir dengan berbagai macam kesempatan kerja (Limpeleh et al, 2019). Terkait teori motivasi Maslow, kebutuhan aktualisasi diri tidak lagi menjadi motivasi utama untuk berperilaku (Ari et al, 2017). Pertimbangan pasar kerja di sini termasuk ketersediaan pekerjaan, keamanan kerja jangka panjang, fleksibilitas karir, dan peluang promosi (Kudadiri \& Hek, 2018). Penelitian oleh Wangarry et al (2018) menemukan pertimbangan di dunia kerja mempunyai pengaruh yang cukup signifikan pada intensi mahasiswa dalam mengejar gelar master di bidang akuntansi. Kesempatan kerja yang tersedia, keamanan kerja, fleksibilitas karir dan peluang promosi membuktikan hal ini. Lulusan dengan pendidikan tinggi memiliki pasar kerja yang luas dan dapat mendorong mahasiswa untuk belajar guna mendapatkan gelar magister di bidang akuntansi.

$\mathrm{H}_{3}$ : Pertimbangan pasar kerja berpengaruh positif terhadap minat mengikuti Pendidikan magister akuntansi.

Keputusan siswa tidak hanya dipengaruhi oleh lingkungan keluarga, tetapi interaksi dengan teman sebaya juga dinilai memiliki pengaruh yang dominan terhadap kepribadian dan pengambilan keputusan individu (termasuk untuk meneruskan Pendidikan ke tahap yang tingkat selanjutnya). Zulfa et al (2018) selain membuat keputusan perihal pendidikan, teman sebaya juga dapat memberikan efek positif lainnya, seperti mendorong individu untuk memulai kegiatan wirausaha (Lingappa et al, 2020). Pendidikan et al (2018) juga membuktikan hal tersebut, menunjukkan bahwa semakin banyak teman sebaya mendukung siswa, seperti mengajarkan interaksi sosial, memberikan pengetahuan, pengalaman dan keterampilan, serta memberikan dukungan aktif lainnya, maka dapat dikatakan lingkungan teman sebaya mampu mendorong mahasiswa dalam mengejar pendidikan magister akuntansi.

$\mathrm{H}_{4}$ : Lingkungan teman sebaya berpengaruh positif terhadap minat mengikuti

Pendidikan magister akuntansi.

Motivasi adalah keinginan kuat yang mendorong individu atau kelompok mencapai tujuan yang ditetapkan. Indikator yang digunakan untuk mengukur motivasi meliputi peluang promosi, kemampuan tampil di tempat kerja, dan hubungan dengan lingkungan kerja dan perluasan jaringan.

Akreditasi program studi merupakan sistem penilaian dalam rangka menentukan kelayakan suatu program studi. Indikator yang digunakan untuk mengukur akreditasi program studi antara lain kinerja tata kelola, mutu produktivitas luaran dan mutu hasil, mutu proses, mutu input.

Pertimbangan pasar kerja mencakup keselamatan kerja, ketersediaan peluang kerja, atau akses mudah ke peluang kerja. Dalam mengukur pertimbangan pasar kerja digunakan beberapa indicator diantaranya ketersediaan pekerjaan, keselamatan kerja, dan fleksibilitas kerja.

Lingkungan teman sebaya mengacu pada lingkungan di mana orang-orang dengan usia dan status yang sama sering sering melakukan interaksi. Indikator yang digunakan untuk mengukur lingkungan teman sebaya antara lain interaksi sosial, kebiasaan teman sebaya, kemauan meniru, memberikan pengalaman baru dan memberikan dukungan. 
Teknik analisis regresi linear berganda adalah teknik analaisis yang digunakan pada penelitian ini. Model analisis regresi linear berganda dalam penelitian ini dinyatakan sebagai berikut.

\section{METODE PENELITIAN}

Fakultas Ekonomi dan Bisnis Universitas Udayana adalah lokasi dilakukannya penelitian. Penelitian ini bertujuan untuk menguji motivasi, akreditasi program studi, pertimbangan pasar kerja, serta lingkungan teman sebaya pada minat mahasiswa akuntansi universitas udayana dalam memperoleh gelar magister akuntansi.

Motivasi adalah keinginan kuat yang mendorong individu atau kelompok mencapai tujuan yang ditetapkan. Indikator yang digunakan untuk mengukur motivasi meliputi peluang promosi, kemampuan tampil di tempat kerja, dan hubungan dengan lingkungan kerja dan perluasan jaringan.

Akreditasi program studi merupakan sistem penilaian dalam rangka menentukan kelayakan suatu program studi. Indikator yang digunakan untuk mengukur akreditasi program studi antara lain kinerja tata kelola, mutu produktivitas luaran dan mutu hasil, mutu proses, mutu input.

Pertimbangan pasar kerja mencakup keselamatan kerja, ketersediaan peluang kerja, atau akses mudah ke peluang kerja. Dalam mengukur pertimbangan pasar kerja digunakan beberapa indicator diantaranya ketersediaan pekerjaan, keselamatan kerja, dan fleksibilitas kerja.

Lingkungan teman sebaya mengacu pada lingkungan di mana orang-orang dengan usia dan status yang sama sering sering melakukan interaksi. Indikator yang digunakan untuk mengukur lingkungan teman sebaya antara lain interaksi sosial, kebiasaan teman sebaya, kemauan meniru, memberikan pengalaman baru dan memberikan dukungan.

Teknik analisis regresi linear berganda adalah teknik analaisis yang digunakan pada penelitian ini. Model analisis regresi linear berganda dalam penelitian ini dinyatakan sebagai berikut.

$$
\mathrm{Y}=\mathrm{\alpha}+\beta_{1} X_{1}+\beta_{2} X_{2}+\beta_{3} X_{3}+\beta_{4} X_{4}+\varepsilon
$$

Keterangan :

$\mathrm{Y}=$ Minat mahasiswa mengikuti pendidikan magister akuntansi

a $=$ Konstanta

$\beta_{1}=$ Koefisien regresi Motivasi

$\beta_{2}=$ Koefisien regresi akreditasi program studi

$\beta_{3}=$ Koefisien regresi pertimbangan pasar

$\beta_{4}=$ Koefisien regresi lingkungan teman sebaya

$\mathrm{X}_{1}=$ Motivasi

$\mathrm{X}_{2}=$ Akreditasi Program Studi

$\mathrm{X}_{3}=$ Pertimbangan pasar kerja

$\mathrm{X}_{4}=$ Lingkungan teman sebaya

$\varepsilon=$ Variabel pengganggu

Berdasarkan analisis data yang dilakukan dapat diamati mengenai uji kelayakan model (uji f), koefisien determinasi (R2) dan uji hipotesisi (Uji t). 


\section{HASIL DAN PEMBAHASAN}

Uji normalitas dalam penelitian memiliki tujuan menguji apakah model regresi yang dibentuk mempunyai distribusi yang normal atau tidak. Uji KolmogorovSmirnov untuk melihat normalitas residual. Data penelitian berdistribusi normal apabila nilai Asymp. Sig. (2-tailed) $>\mathrm{a}=0,05$. Adapun hasil pengujian normalitas dalam penelitian ini terlihat pada Tabel 2 .

Tabel 2. Hasil Uji Normalitas

\begin{tabular}{lll}
\hline & & Nilai \\
\hline Normal Parameters & Mean & 168 \\
& Std. Deviation & 0,0000000 \\
Most Extreme Differences & Absolute & $453,856,560$ \\
& Positive & 0,068 \\
Kolmogorov-Smirnov Z & Negative & 0,051 \\
Asymp. Sig. (2-tailed) & Mean & $-0,068$ \\
\end{tabular}

Sumber: Data Penelitian, 2020

Berdasarkan uji normalitas pada Tabel 2, terlihat bahwa nilai signifikansi adalah sebesar 0,059 lebih besar dari level of significant (tingkat signifikansi) yaitu 0,05 , artinya, model persamaan regresi memiliki distribusi normal.

Uji multikolinearitas digunakan demi menguji apakah variabel independen yang digunakan memiliki kemiripan antar variabel independen. Multikolinearitas dapat dilihat dari nilai toleransi atau variance inflation factor (VIF). Jika nilai toleransi masing-masing variabel kurang dari 10, berarti model regresi tidak terjadi multikolinieritas. Tabel 3, mencantumkan hasil uji multikolinearitas.

Tabel 3. Hasil Uji Multikolinearitas

\begin{tabular}{lcc}
\hline Variabel & Tolerance & VIF \\
\hline Motivasi & 0,598 & 1,672 \\
Akreditasi Program Studi & 0,796 & 1,257 \\
Pertimbangan Pasar Kerja & 0,603 & 1,658 \\
Lingkungan Teman Sebaya & 0,631 & 1,584 \\
\hline
\end{tabular}

Sumber: Data Penelitian, 2020

Menurut hasil uji multikolinearitas pada Tabel 3, telihat bahwa variabel bebas dalam penelitian ini yaitu motivasi, akreditasi program studi, pertimbangan pasar kerja dan lingkungan teman sebaya memiliki nilai tolerance $>0,10$ dan nilai VIF < 10. Ini berarti, variabel bebas dalam penelitian ini bebas dari gejala multikolinearitas, jadi tidak terdapat kolerasi antar variabel bebas. 


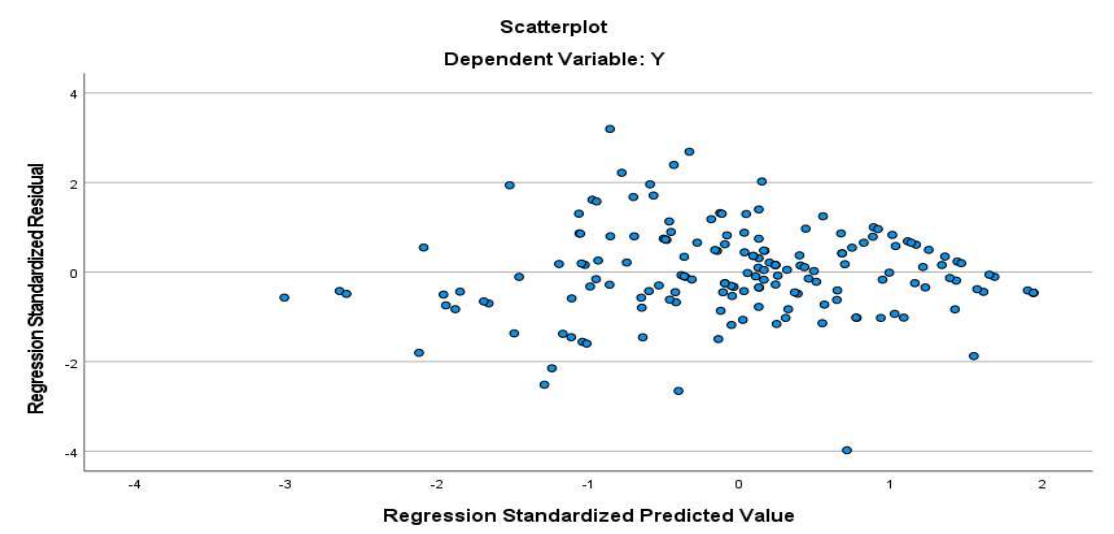

Sumber: Data Penelitian, 2020

Grafik 1. Hasil Uji Heteroskedastisitas

Uji heteroskedastisitas diperlukan guna mengetahui apakah variasi residual dari satu pengamatan ke pengamatan lainnya mengalami ketidaksamaan dalam model regresi. Model regresi dikatakan bagus apabila gejala heteroskedastisitas tidak ditemukan, yang mana varian residual dari satu observasi ke observasi lainnya tetap. Berdasarkan hasil uji heteroskedastisitas pada Gambar 1 dapat diketahui bahwa sebaran titik data tidak membentuk pola apapun, sehingga dalam model regresi tidak terdapat heteroskedastisitas.

Tabel 4. Hasil Regresi Linear Berganda

\begin{tabular}{|c|c|c|c|c|c|c|}
\hline \multirow{2}{*}{\multicolumn{2}{|c|}{ Model }} & \multicolumn{2}{|c|}{$\begin{array}{l}\text { Unstandardized } \\
\text { Coefficients }\end{array}$} & \multirow{2}{*}{$\begin{array}{c}\begin{array}{c}\text { Standardized } \\
\text { Coefficients }\end{array} \\
\text { Beta }\end{array}$} & \multirow[t]{2}{*}{$\mathrm{t}$} & \multirow[t]{2}{*}{ Sig. } \\
\hline & & B & Std. Error & & & \\
\hline \multirow[t]{5}{*}{1} & (Constant) & -12.122 & 3.560 & & -3.404 & 0.001 \\
\hline & Motivasi & 0.698 & 0.140 & 0.294 & 4.992 & 0.000 \\
\hline & $\begin{array}{l}\text { Akreditasi } \\
\text { Prodi }\end{array}$ & 0.236 & 0.174 & 0.069 & 1.351 & 0.179 \\
\hline & $\begin{array}{l}\text { Pertimbangan } \\
\text { Pasar Kerja }\end{array}$ & -0.097 & 0.208 & 0.027 & -0.468 & 0.640 \\
\hline & Teman Sebaya & 0.924 & 0.087 & 0.611 & 10.675 & 0.000 \\
\hline
\end{tabular}

Sumber: Data Penelitian, 2020

Berdasarkan hasil analisis regresi linear berganda pada Tabel 4, persamaan regresinya adalah berikut ini.

$$
\mathrm{Y}=-12,122+0,698 \mathrm{X} 1+0,236 \mathrm{X} 2-0,097 \mathrm{X} 3+0,924 \mathrm{X} 4+\varepsilon
$$

Nilai konstanta $-12,122$ artinya jika motivasi (X1), akreditasi program studi (X2), pertimbangan pasar kerja (X3) dan lingkungan teman sebaya (X4) dianggap tetap nol, maka minat mahasiswa untuk memperoleh gelar magister akuntansi (Y) akan mengalami penurunan 12.122 satuan. Nilai koefisien $\beta 1=0,698$ menunjukkan bahwa jika motivasi (X1) meningkat satu satuan, maka minat memperoleh gelar magister akuntansi akan menurun, yang ditunjukkan dengan peningkatan nilai $Y$ sebesar 0,698 dengan asumsi variabel lainnya konstan. Nilai koefisien Nilai koefisien $\beta 2=0,236$ menunjukkan bahwa apabila akreditasi program studi meningkat satu satuan, minat mahasiswa pada program magister 
akuntansi tidak akan berubah, yang ditunjukkan dengan nilai signifikansi lebih besar dari 0,05. B3 $=-0,097$ artinya jika pertimbangan pasar kerja meningkat satu satuan, minat mahasiswa untuk memperoleh gelar magister akuntansi tidak akan berubah, dan nilai signifikansinya lebih besar dari 0,05 . Nilai koefisien $\beta 4=0,924$ menunjukkan bahwa jika lingkungan teman sebaya meningkat sebesar satu satuan, maka minat melanjutkan pendidikan magister di bidang akuntansi meningkat senilai 0,924 satuan. Dengan asumsi variabel lain konstan.

Analisis statistik deskriptif bertujuan untuk memberikan informasi masingmasing variabel penelitian, diantaranya mean, minimum, maksimum dan standar deviasi. Hasil analisis deskriptif dari variabel motivasi mempunyai skor jawaban sebesar 10 sampai dengan 25 dengan nilai rata-rata jawaban responden terhadap pernyataan variabel motivasi sebesar 19,4286 dan nilai standar deviasi sebesar 3,28774 dari 168 responden. Variabel akreditasi program studi mempunyai skor jawaban sebesar $14 \mathrm{~s} / \mathrm{d}$ 25, nilai rata-rata (mean) jawaban responden terhadap pernyataan variabel akreditasi program studi yakni 21,9405, nilai standar deviasi sebesar 2,28429 dari 168 responden. Variabel pertimbangan pasar kerja mempunyai skor jawaban sebesar $4 \mathrm{~s} / \mathrm{d} 15$ dengan nilai rata-rata jawaban responden terhadap variabel pertimbangan pasar kerja yaitu 11,2857 serta nilai standar deviasi sebesar 2,19728 dari 168 responden. Variabel lingkungan teman sebaya mempunyai skor jawaban sebesar 11 sampai dengan 35 dengan rata-rata jawaban responden terhadap variabel lingkungan teman sebaya sebesar 26,2381 dan nilai standar deviasi sebesar 5,16580 dari 168 responden. Variabel minat mengikuti pendidikan magister akuntansi memperoleh skor jawaban sebesar 8 sampai dengan 40 dengan rata-rata jawaban responden terhadap variabel minat mengikuti pendidikan magister akuntansi sebesar 7,81368 dari 168 responden.

Koefisien determinasi (R2) digunakan untuk mengetahui kemampuan model dalam menjelaskan variasi variabel independent. Nilai dari koefisien determinasi adalah antara nol hingga satu. Koefisien determinasi dapat dilihat dari nilai Adjusted $\mathrm{R}^{2}$. Berdasarkan hasil uji $\mathrm{R}^{2}$ dapat disimpulkan bahwa nilai Adjusted $\mathrm{R}^{2}$ sebesar 0,663 mempunyai arti bahwa sebesar 66,3\% variasi minat mahasiswa mengikuti pendidikan magister akuntansi dipengaruhi oleh variasi motivasi, akreditasi program studi, pertimbangan pasar kerja dan lingkungan teman sebaya, sedangkan sisanya sebesar 33,7\% dijelaskan oleh faktor lain diluar model penelitian.

Uji F digunakan untuk mengetahui apakah model regresi dalam penelitian ini dinyatakan layak untuk digunakan. Uji $\mathrm{F}$ dilakukan dengan melihat nilai signifikan pada tabel annova dalam SPSS. Apabila signifikansi annova lebih kecil dari 0,05 maka variabel independen secara bersama-sama berpengaruh positif terhadap variabel dependen. Berdasarkan hasil uji $\mathrm{F}$ memperlihatkan hasil perhitungan $F$ yang memperoleh angka sebesar 80,032 dengan tingkat signifikansi $<0,05$, sehingga dapat disimpulkan bahwa model tersebut layak untuk penelitian.

Uji hipotesis (uji t) memiliki tujuan mengetahui pengaruh dari setiap variabel independent pada variabel dependennya. Uji t dilakukan dengan cara melihat nilai signifikansinya. Apabila tingkat signifikansi $t>0,05$, maka $\mathrm{H0}$ diterima dan $\mathrm{H} 1$ ditolak. Sebaliknya, jika tingkat signifikan dari $\mathrm{t} \leq 0,05$, maka H0 ditolak dan $\mathrm{H}_{1}$ diterima. 
Hipotesis pertama $\left(\mathrm{H}_{1}\right)$ yaitu motivasi mempunyai pengaruh positif terhadap minat mengikuti pendidikan magister akuntansi. Hasil analisis pada Tabel 4, menyatakan nilai koefisien variabel motivasi positif sebesar 0,294 dengan tingkat signifikansi sebesar 0,000 yang lebih kecil dari alpha yaitu 0,05. Hal ini menunjukkan bahwa tingkat motivasi mempunyai pengaruh pada intensi/minat mahasiswa dalam mengikuti pendidikan magister akuntansi. Tingginya motivasi mahasiswa dapat berpengaruh pada tingginya minat. Dengan demikian hipotesis pertama $\left(\mathrm{H}_{1}\right)$ dalam penelitian ini diterima.

Hasil penelitian ini sejalan dengan penelitian Verawati (2016) yang menjelaskan, motivasi memiliki pengaruh positif pada intensi mahasiswa dalam menempuh pendidikan magister akuntansi. Penelitian ini didasarkan pada teori motivasi Maslow, dimana setiap orang bisa termotivasi dengan alasan keamanan, yaitu pada pernyataannya, mahasiswa tertarik untuk melanjutkan studi magister akuntansi guna banyak kesempatan kerja , dan responden dominan jawabannya setuju dan sangat setuju, artinya lulusan magister dapat menjamin rasa amannya.

Hipotesis kedua $\left(\mathrm{H}_{2}\right)$ menyatakan bahwa akreditasi program studi berpengaruh positif terhadap minat mengikuti Pendidikan magister akuntansi. Hasil analisis pada Tabel 4, menyatakan nilai koefisien regresi sebesar 0,069 dengan tingkat signifikansi 0,179 yang lebih besar dari alpha yaitu 0,05. Hal ini menunjukkan bahwa akreditasi suatu program studi tidak mempunyai pengaruh pada minat mengikuti pendidikan magister akuntansi. Dengan demikian, hipotesis kedua $\left(\mathrm{H}_{2}\right)$ dalam penelitian ini ditolak.

Hasil penelitian ini tidak sejalan dengan penelitian Verawati (2016) yang menunjukkan bahwa akreditasi program studi berpengaruh positif terhadap minat mahasiswa dalam memperoleh gelar magister akuntansi. Hasil penelitian ini gagal membuktikan penerapan teori motivasi Maslow sebagai teori dasar penelitian. Hasil penelitian ini menunjukkan bahwa akreditasi suatu program studi tidak berpengaruh pada intensi mahasiswa untuk memperoleh gelar magister akuntansi, artinya akreditasi suatu program studi tidak berpengaruh terhadap minat mengikuti program magister akuntansi. Faktor yang mengakibatkan hal ini terjadi adalah karena beberapa mahasiswa yang berminat untuk melanjutkan studi magister cenderung lebih mengutamakan kebutuhan melanjutkan pendidikan dibandingkan dengan pengakuan terhadap akreditasi program studi.

Hipotesis ketiga $\left(\mathrm{H}_{3}\right)$ yaitu pertimbangan pasar kerja memiliki pengaruh positif tidak signifikan pada minat memperoleh gelar magister akuntansi. Hasil analisis pada Tabel 4, memperlihatkan, nilai koefisien regresi yakni 0,027 dan signifikansinya 0,64 yang lebih besar dari nilai a $(0,05)$. Hal ini menunjukkan bahwa pertimbangan pasar kerja tidak berpengaruh terhadap minat memperoleh gelar master di bidang akuntansi. Oleh karena itu, hipotesis ketiga dalam penelitian ini ditolak.

Hasil penelitian ini sejalan dengan penelitian oleh Hutapea (2017) yang menyebutkan bahwa pertimbangan pasar kerja tidak berpengaruh pada minat mahasiswa mengikuti pendidikan magister. Namun hal tersebut, bertentangan dengan penelitian Primashanti et al. (2017) dimana pertimbangan pasar kerja mempengaruhi intensi mahasiswa mengikuti pendidikan magister. 
Hipotesis keempat $\left(\mathrm{H}_{4}\right)$ menyatakan bahwa lingkungan teman sebaya berpengaruh positif terhadap minat mengikuti program magister pendidikan akuntansi. Tabel 4, memperlihatkan nilai koefisien regresi sebesar 0,611 dan nilai signifikansi 0,000 lebih kecil dari nilai a (yaitu 0,05). Hal ini menunjukkan bahwa lingkungan teman sebaya akan mempengaruhi minat belajar magister akuntansi. Dengan demikian hipotesis keempat diterima.

Hasil penelitian ini mendukung penelitian Pendidikan et al. (2018) yang menemukan bahwa lingkungan teman sebaya berpengaruh positif terhadap minat mendaftar di program magister akuntansi. Penelitian ini sejalan dengan teori motivasi Maslow bahwa kebutuhan akan rasa aman dalam pernyataan bahwa teman sebaya selalu mendukung keputusan individu perihal dunia pendidikan, banyak diantara mereka menjawab pernyataan tersebut dengan setuju dan sangat setuju yang berarti bahwa lingkungan teman sebaya dapat menjamin bahwa seseorang diterima. dalam lingkup pertemanan.

\section{SIMPULAN}

Berdasarkan hasil analisis informasi dan pembahasan yang dilakukan, dapat disimpulkan bahwa motivasi dan lingkungan teman sebaya berpengaruh positif terhadap minat mahasiswa dalam mengikuti pendidikan magister akuntansi, akreditasi program studi, dan pertimbangan pasar kerja. Itu tidak berpengaruh pada niat mahasiswa dalam menempuh program magister akuntansi. Ini berarti, semakin baik akreditasi rencana studi dan pertimbangan pasar tenaga kerja, belum tentu akan mempengaruhi minat mahasiswa pada minat mengikuti program magister akuntansi.

Berdasarkan simpulan yang dipaparkan, saran yang penulis usulkan kepada peneliti selanjutnya adalah dengan memperluas populasi penelitian sehingga hasil dapat digeneralisasi. Selain itu, populasi sebaiknya tidak hanya mahasiswa jurusan akuntansi di Universitas Udayana saja, tetapi juga mahasiswa dari universitas lain. Serta, peneliti selanjutnya dapat meneliti variabel independen lain yang diduga berpengaruh pada intensi/minat mahasiswa mengikuti pendidikan magister akuntansi, contohnya faktor latar belakang sosial-ekonomi keluarga, faktor strategi komunikasi, seperti seminar serta faktor lainnya.

\section{REFERENSI}

Ari, K. B. J., Wahyuni, M. A., \& Sulindawati, N. L. G. E. (2017). Pengaruh Faktor Gender, Pertimbangan Pasar Kerja, Lingkungan Kerja, Penghargaan Finansial dan Pelatihan Profesional Terhadap Minat Mahasiswa dalam Berkarir sebagai Akuntan Publik. E-Journal Universitas Pendidikan Ganesha, $8(2)$.

Aryani, N. P. D., \& Erawati, N. M. A. (2016). Pengaruh Motivasi Kualitas, Karir, Ekonomi, Dan Biaya Pendidikan Pada Minat Mahasiswa Mengikuti Pendidikan Profesi Akuntansi. E-Jurnal Akuntansi, 16(1), 362-384.

Bozek, B., Raeymaeckers, P., \& Spooren, P. (2017). De motivaties van studenten in de master sociaal werk: een typologie. European Journal of Social Work, 20(3), 409-421. https:/ / doi.org/10.1080/13691457.2017.1283587

Byrne, M., Flood, B., Hassall, T., Joyce, J., Arquero Montaño, J. L., González González, J. M., \& Tourna-Germanou, E. (2012). Motivations, expectations 
and preparedness for higher education: A study of accounting students in Ireland, the UK, Spain and Greece. Accounting Forum, 36(2), 134-144. https://doi.org/10.1016/j.accfor.2011.12.001

Dalc1, İ., Araslı, H., Tümer, M., \& Baradarani, S. (2013). Factors that influence Iranian students' decision to choose accounting major. Journal of Accounting in Emerging Economies, 3(2), 145-163. https://doi.org/10.1108/20421161311288866

Dary, A. W., \& Ilyas, F. (2019). Pengaruh Gender, Penghargaan Finansial Dan Pertimbangan Pasar Kerja Terhadap Minat Mahasiswa Akuntansi Untuk Berkarir Menjadi Akuntan Publik Dan Non Akuntan Publik. Jurnal Akuntansi, 7(1), 51-60. https://doi.org/10.33369/j.akuntansi.7.1.51-60

Dibabe, T.M. Wubie, A. W. Wondmagegn, G. A. (2015). Factors that Affect Students ' Career Choice in Accounting: A Case of Bahir Dar University Students. Research Journal of Finance and Accounting, 6(5), 146-154.

Dita Verawati. (2016). Melanjutkan Magister Akuntansi ( Studi Empiris pada Mahasiswa Akuntansi di UMS ) ". 1-19.

Durso, S. D. O., Da Cunha, J. V. A., Neves, P. A., \& Teixeira, J. D. V. (2016). Motivational factors for the master's degree: A comparison between students in accounting and economics in the light of the self-determination theory. Revista Contabilidade e Financas, 27(71), 243-258. https://doi.org/10.1590/1808-057x201602080

Hutapea, H. D. (2017). The Perception Of Accounting Students About The Factors Which of Career Selection (Emperis Studi: Accounting Students in MedanNorth Sumatera). Munich Personal RePEc Archive, 77056.

Irma, I., \& Hartati, N. (2019). The Effect of Motivation on the Interest of Accounting Students to Follow Accounting Professional Education. GATR Accounting and Finance Review, 4(3), 79-86. https:// doi.org/10.35609/afr.2019.4.3(3)

Kaplan, S. G., \& Wheeler, E. G. (1983). Survival skills for working with potentially violent clients. Social Casework, 64(6), 339-346. https://doi.org/10.1177/104438948306400603

Kudadiri, M. S., \& Hek, T. K. (2018). Faktor-Faktor Yang Mempengaruhi Keputusan Mahasiswa S-1 Kasus Mahasiswa S-1 Akuntansi Ibbi ) Abstrak / Abstract. Jurnal Bina Akuntansi IBBI Volume 29 No.1 Juni 2018., 29(1), 79-89.

Lim, C., \& Cheaseth Seng, T. (2015). Factors influence students' choice of accounting major in cambodian universities. Asian Review of Accounting, 23(3), 232-255.

Limpeleh, E. A. ., Sondakh, N., Manggopa, R. E., \& Nangoy, S. J. (2019). Analysis of the Impact of Competence and Considerations Market Work Toward Accountant Careers on Polimdo Accounting Students. Scientific Research Journal, 07(10), 30-40. https:// doi.org/10.31364/scirj/v7.i10.2019.p1019707

Lingappa, A. K., Shah, A., \& Mathew, A. O. (2020). Academic, Family, and Peer Influence on Entrepreneurial Intention of Engineering Students. SAGE Open, 10(3). https://doi.org/10.1177/2158244020933877

Lunenburg, F. C. (2011). Expectancy Theory of Motivation : Motivating by Altering Expectations. International Journal of Business Administration, 15(1), 1-6.

Maas, J. D., Keeling, K. O., \& Michenzi, A. R. (2016). Advances in Accounting Education: Teaching and Curriculum Innovations. iii. 
https://doi.org/10.1108/s1085-462220160000018011

Malik, A. D. (2017). Analisa Faktor - Faktor Yang Mempengaruhi Minat Masyarakat Berinvestasi Di Pasar Modal Syariah Melalui Bursa Galeri Investasi Uisi. Jurnal Ekonomi Dan Bisnis Islam (Journal of Islamic Economics and Business), 3(1), 61. https:/ / doi.org/10.20473/jebis.v3i1.4693

Mastura, A., Nuringwahyu, S., \& Zunaida, D. (2020). Pengaruh Motivasi Investasi, Pengetahuan Investasi Dan Teknologi Informasi Terhadap Minat Berinvestasi. Jiagabi, 9(1), 64-75.

Porter, J., \& Woolley, D. (2014). An Examination of the Factors Affecting Students' Decision to Major in Accounting. International Journal of Accounting and Taxation, 2(4), 1-22. https://doi.org/10.15640/ijat.v2n4a1

Primashanti, N. L. C., Herawati, N. T., \& Atmadja, A. T. (2017). Pengaruh Pertimbangan Pasar Kerja, Referents, Dan Nilai Intrinsik Pekerjaan Terhadap Pemilihan Karir Mahasiswa Sebagai Akuntan (Studi Pada Mahasiswa Jurusan Akuntansi Program S1 Universitas Pendidikan Ganesha). E-Journal S1 Ak Universitas Pendidikan Ganesha, 8(2), 1-6.

Putri Dea Giantari, N. L., \& Ramantha, I. W. (2019). Pengaruh Motivasi, Lingkungan Keluarga dan Pendidikan Terhadap Minat Berwirausaha Mahasiswa Jurusan Akuntansi Reguler. E-Jurnal Akuntansi, 28, 1. https://doi.org/10.24843/eja.2019.v28.i01.p01

Surya B., I. G. A. D., \& Budiasih, I. G. A. N. (2019). Pengaruh Motivasi dan Persepsi Biaya Pendidikan pada Minat Mahasiswa Mengikuti Pendidikan Magister $\begin{array}{llll}\text { Akuntansi. E-Jurnal } & \text { Akuntansi, }\end{array}$ https:// doi.org/10.24843/eja.2019.v28.i02.p06

Udayana, E. A. U. (2017). Pengaruh Motivasi, Biaya Pendidikan Dan Lama Pendidikan Pada Minat Mahasiswa Akuntansi Mengikuti Ppak. E-Jurnal Akuntansi, 2017(1), 447-476.

van Zyl, C., \& de Villiers, C. (2011). Why some students choose to become chartered accountants (and others do not). Meditari Accountancy Research, 19(1/2), 56-74. https:// doi.org/10.1108/10222521111178637

Wangarry, R., Sondakh, J., \& Budiarso, N. S. (2018). Analisis Faktor-Faktor Yang Mempengaruhi Minat Mahasiswa Akuntansi Mengikuti Pendidikan Profesi Akuntansi. Going Concern: Jurnal Riset Akuntansi, 13(04), 108-119. https://doi.org/10.32400/gc.13.03.20040.2018

Wheeler, K. G. (1983). Perceptions of labor market variables by college students in business, education, and psychology. Journal of Vocational Behavior, 22(1), 111. https:// doi.org/10.1016/0001-8791(83)90002-7

Zulfa, N. I., Heryaniningsih, S. M., Saputra, M. R., \& Putri, M. K. (2018). Pengaruh Teman Sebaya Terhadap Minat Melanjutkan Studi Ke Perguruan Tinggi pada Siswa SMA. Journal of Innovative Counseling: Theory, Practice \& Research, 2(2), 69-74. 